\title{
Transatlantic crossing in the 1920s and 30 s - the trajectories of the European poetic and scientific avant-garde in Brazil
}

Ellen Spielmann ${ }^{a}$

\begin{abstract}
This article focuses on four paradigmatic cases of travelers. The central part concerns Dina Lévi-Strauss who gave the first course on modern ethnography in Brazil. She transfered the very latest: her projects include the founding of an ethnographic museum modeled on the "Musée de l'Homme". Claude LéviStrauss and Fernand Braudel traveled to São Paulo as members of the French mission, which played an important role in the founding of the University of São Paulo. For political reasons Claude Lévi-Strauss' contract at the University was not renewed in 1937. Blaise Cendrars was already a famous poet when he crossed the Atlantic in 1924. Fascism in Europe and World War II interrupted the careers of these four travelers as well as their interchanges with Brazil and their Brazilian friendships. But Brazilian experiences of Claude Lévi-Strauss and Braudel are crucial for their successful careers, after 1945.
\end{abstract}

Keywords: Transatlantic crossing 20th Century, history of science, poetic and scientific avant-garde, University of São Paulo, Dina and Claude LéviStrauss, Fernand Braudel, Blaise Cendrars, Paulo Prado, Musée de l'Homme.

Recebido em 21 de março de 2016 Aceito em 31 de março de 2016

a Professora e pesquisadora em Teoria literária e cultural da América Latina na Univ. de Tübingen, ellen-spielmann@t-online.de. 
${ }^{1}$ Michel Foucault's definition of the term: "La transgression est une geste qui concerne la limite [...]. Quel est l'espace propre de cette pensée et quelle langage peut-elle se donner? [...] Seraitil d'un grand secours de dire, par analogie, qu'il faudrait trouver pour le transgressif un langage qui serait ce que la dialectique a été pour la contradiction?" (1963/1994: 236, 241).

${ }^{2}$ Representive studies on Cendrars, see for example Chefdor, Monique 1989. “Interou Transnationalité de Blaise Cendrars. Ebauche d'une ethnocritique". In: Flückinger, Jean-Carlo (Hg.) 1989. L'encrier de Cendrars. Cahiers Blaise Cendrars. Nr. 3, Actes du Colloque du Centenaire 1987. Bern: Éditions de la Baconnière. p. 149157 ; Leroy, Claude 2014. Dans l'atelier de Cendrars. Paris: Champion.
During the 1920s and 1930s various members of the European avant-garde traveled to Brazil. Their travels produced culturally-specific representations, which bore witness to travel but at the same time were the result of spatial displacement.

I would like to focus on four cases. The first traveler is the French-Swiss poet, Blaise Cendrars. In 1924 and 1926-27 he was invited by the São Paulo coffee king and patron of the arts, Paulo Prado, to perform avant-garde projects in Brazil. The three others, who crossed the Atlantic in 1935 to undertake historical or ethnological studies, are French - the young historian Fernand Braudel, and the young ethnologist, Dina Lévi-Strauss, who graduated from Paris, and her husband, Claude, a philosophy teacher, and a socialist.

As is widely known Claude Lévi-Strauss' great book, Tristes tropiques, begins with the words, "I hate traveling and explorers". What interests me is analyzing and describing the routes of displacement of these four travelers in their multiple locations, and the significance that their trajections held for them. The term trajection (better than trajectory) will be explored in its different metaphoric meanings (cross over, passage, transgression). ${ }^{1}$ I would like to focus equally on the results of the journeys and what was lost during them. The central part of my presentation concerns Dina Lévi-Strauss, who has been lost to the history of science, and about whose existence next to nothing was known on either side of the Atlantic until recently.

\section{1}

The poet Blaise Cendrars knows all territories of the world, he is a cosmopolitan stroller, who crossed, transgressed, who blurred borders, succeeded in finding innovative and dissonant forms of representation and dissolution of representation in his poem La prose du Transsiberién published in 1913. In his understanding, avant-garde poetique is a transcultural experimental field. ${ }^{2}$ The invitation to cross the Atlantic was a big deal for him, his goal was to understand, to transgress while at Brazil, the country of Coffee and Adventure. After his journeys, the poet became a successful novel writer, but his ambitious projects on Brazil in terms of writing and producing movies failed ultimately. Even though he produced several 
types of text and went through different genres. Why? In my reading, the results of his Brazilian enterprise are attempts of cultural translation. As we all know, translation is a tricky thing. I use the notion of cultural translation here within the definition of postcolonial English anthropology. The critic Ross King writes: "Ideas and images have always been translated translinguistically and across space - from one place or city or hemisphere to another. But in these decades from 1900 to around 1930 they are also translated across political economies - different worldviews and fundamentally different social constructions of space (and time) itself". Then King articulates the crucial question: "All translation confronts a dilemma: Where is it that ideas and images are to be found? (...) in the utterance, or in the voice on which it rides? So what, ultimately, can be translated?" (KING, 1996, p. 71-72). Blaise Cendrars has been confronted exactly with this dilemma, his very interesting experimental involvements in the process of cultural translation finally did not succeed. ${ }^{3}$

\section{2}

In the 1930s, after the Crash at Wall Street in 1929 and the following worldwide economic crisis, the most unexpected happened, the situation changed completely. The official nationalist discourse coming up in the 1920s and more strongly in the 1930s in Brazil has been decisive for the handling of technologic and scientific transfer. São Paulo's elite was mainly interested in industrializing their country, they planned an autonomous independent scientific production in Brazil. The University of São Paulo was founded. The founding took place with the help of an official scientific mission from France. Fernand Braudel, Claude and Dina Lévi-Strauss traveled to São Paulo as members of the French mission (SPIELMANN, 2003).

Let's look at Braudel, the important historian, leader of the Annales-School. He started his career in São Paulo. In my reading, his journey to Brazil is an enterprise of travelling in time. In Brazil, he discovers new concepts and notions

${ }^{3}$ For elaboration of this hypothesis, se my forthcoming study on this topic by Wissenschaftlicher Verlag Berlin 2017. for writing and thinking History, for example, the Longue durée approach to stress the slow and often imperceptible effects of space, climate and technology on human life in the past. By crossing the Atlantic he discovers the crucial role 
of the Atlantic in the relationship between metropolis and periphery. Braudel founded the special field in historiography: transatlantic History. Later on in La civilisation matérielle, économie et capitalisme (XVe - XVIIIe siècle) (1979) he develops the notion "Ancien Régime (biologique)" in contrast to the "Nouveau Régime", based on the analysis of historical and living conditions from 1400 to 1800. It is a key concept even for today's understanding of the global world. ${ }^{4}$

The central part of my contribution concerns the journey of a young French scientist, who has been lost to the history of science within the national scientific genealogy of Brazil, and about whose existence next to nothing was known on either side of the Atlantic until the beginning of 2000: Dina LéviStrauss. What follows is the result of my research in Brazilian archives and elsewhere (SPIELMANN, 2003).

As a graduate ethnologist, a student of Marcel Mauss, and most importantly a foster child of Paul Rivet, the great Americanist and later director of the "Musée de l'Homme", she moved from Paris to São Paulo in 1935 with her husband Claude. In the same year, she was appointed professor of ethnography by the director of the Secretary of culture of São Paulo, who was none other than Mário de Andrade. Between May and October 1935, Dina Lévi-Strauss gave the first course on modern ethnography in the history of the discipline in Brazil. She transferred the very latest: Mauss' "instructions" on the ethnographical collecting process were the point of reference for the opening lecture. ${ }^{5}$

Dina Lévi-Strauss was a professional in the field of anthropological photography and film. Various pieces of equipment, camera types, lenses, angles, apertures, formats

${ }^{4}$ See footnote 2 .

${ }^{5}$ See document SEF 1 , cx 1 , doc. 4 - Sociedade de Etnografia e Folclore ("Society for Ethnography and Folklore") of Acervo Histórico da Discoteca Oneyda Alvarenga (Historical Arquive) of Centro Cultural de São Paulo. and how they work were explained in one whole session. Dina delivered a crash course in modern ethnography with the latest theoretical and practical knowledge. In 1936 the course was published in Portuguese as a handbook with photographs by São Paulo's Secretary of culture under the title Instruções práticas para pesquisas de Antropologia física e cultural.

In 1936 Dina Lévi-Strauss and Mário de Andrade founded the "Society for Ethnography and Folklore" in São Paulo, which 
has been carrying out excursions, collecting, questionnaires and lectures since 1937. Other projects include the founding of an ethnographic museum modeled on the "Musée de l'Homme" and a dictionary for ethnography and folklore.

Dina's husband, Claude Lévi-Strauss, traveled to São Paulo in 1935 as, I repeat, a member of the French mission, which played an important role in the founding of the University of São Paulo. He basically owed his invitation to his wife's scientist-foster parent, Paul Rivet. Claude left his fouryear career as a teacher of philosophy in the province behind him to become a sociologist and a Durkheimian, second or third generation student of Durkheim - or at least that is how the Brazilians understood it. Yet, contrary to the expectations of the Brazilians, he turned out to be "against philosophy and against Durkheim" (LÉVI-STRAUSS, 1996, p. 9)

What is significant however is that under his wife's instructions he learned the basics of ethnography in Brazil.

In 1935-1936, Dina Lévi-Strauss traveled with Claude to the backland regions, to Mato Grosso, to the Bororo and Kaduweu Indians to carry out field research. While with the Kaduweu Indians they encountered face and body painting. Only women practiced this art on other women. Dina photographed and filmed it. The couple collected several series of drawings and commissioned drawings. Claude Lévi-Strauss later based his fundamental differentiation between art as a system of signs and art as mimesis on the important art form of the Kaduweu Indians.

Five films were made during the journey. The names of Dina and Claude Lévi-Strauss appeared in big letters in the credits. It is, however, quite obvious who the professional was: Dina Lévi-Strauss. Thanks to her knowledge and good contacts, the expedition was funded by São Paulo's Secretary of Culture and the Musée de l'Homme. The results of the "Ethnologic Mission to Brazil" were exhibited in Paris a year later under the title "Indians of Mato Grosso." Eighty-four objects, including ceramics, weapons and religious artifacts, went on display at the "Musée de l'Homme." Rivet wrote the foreword of the small exhibition catalogue: as scientists involved in the four-month field study and authors of the catalogue, he congratulated Prof. Claude Lévi-Strauss of the 
University of São Paulo and Madame Lévi-Strauss, Professor of Ethnography of the city of São Paulo.

During their stay in Paris, a major expedition project to visit the Nambikwara Indians in Mato Grosso was planned, which was set to take place thanks to the help of Rivet. Obtaining approval for the journey involved a long drawn-out dispute as it was a contentious issue for political reasons. The Brazilian government of Estado Novo did not want to give approval to a foreign expedition involving the socialist Rivet, who was now an exposed figure in the "Front Populaire." However, the Brazilian-French Commission finally reached agreement a year later. The condition was that the expedition be accompanied and controlled by a Brazilian official observer. At the beginning of June 1938, Dina and Claude Lévi-Strauss traveled to the Nambikwara accompanied by an official observer from Getúlio Vargas' government.

During the journey, Claude Lévi-Strauss carried out the first and only field study of his life. Based on this work, he wrote the monographic study "La vie familiale et sociale des indiens Nambikwara" (1948) for which he received an academic title, thus legitimizing himself as ethnologist.

Photographs of the expedition show the ethnologist Dina Lévi-Strauss during field studies. She was, however, forced to return to São Paulo before the end of the expedition due to an eye-illness. She returned to Paris in November 1938. With her absence from Brazil, the disappearance process abruptly started. This has mainly to do with how scientific genealogies are built under the pressure of nationalistic imperative.

Claude Lévi Strauss' encounter with the linguist Roman Jacobson in New York and his adoption of structuralism will always be considered the decisive moment. Yet this method only acquires significance as a result of the ethnology that he learned from and with Dina.

For political reasons Claude Lévi-Strauss' contract at the University was not renewed in 1937. Fascism in Europe and World War II interrupted the careers of these four travelers as well as their interchanges with Brazil and their Brazilian friendships. But the Brazilian experiences of Claude Lévi-Strauss and Braudel are crucial for their successful careers, after 1945. 
Instead of a conclusion I would like to portray each of the travelers.

First: The image I would like to evoke of Blaise Cendrars is the one portraying the poet with a video hand camera working out his very willful poetic experiences and imaginations in order to catch Brazil.

Second: The portrait of Fernand Braudel is one of the old and wise historian giving testimony on how he was shaped as a historian. In his "Personal Testimony" Braudel writes: "Brazil was the greatest period of my life. I became intelligent by going to Brazil. What I saw there was a historical spectacle, a spectacle of such social kindness (...) that I came to understand life in a different way. The best years of my life were those I spent in Brazil"' (1972, p. 448).

Third: The image I would like to evoke of Claude LéviStrauss is the one with the traveler crossing the Atlantic in 1941. On his way to exile in the USA, in the middle of the ocean, he told his fellow travelers, André Breton and the great painter Wilfredo Lam, about the religious performances and dances of the Bororo Indians.

And, finally, the picture of an ethnologist, imitating the gesture of her interlocutor, learning how Nambikwara-women use to sit. This is, of course, Dina Lévi-Strauss, about whom I wanted to pay special attention.

\section{REFERENCES}

BRAUDEL, Fernand, Personal Testimony. Jornal of Modern History, v. XLIV, n. 4, 1972, p. 448-467.

FOUCAULT, Michel. Dits et écrits. Bd. I. Paris: Gallimard, 1963/1994, 1969.

KING, Ross "The 1920s as Crucible: Translation, Vkhutemas, and the Bauhaus". In: Emancipating Space. Geography, Architecture, and Urban Design. New York/London: The Guilford Press, 1996, p. 71-72.

LÉVI-STRAUSS, Claude. Saudades de São Paulo. Trad. de Paulo Neves. São Paulo: Companhia das Letras, 1996. 
LÉVI-STRAUSS, Dina. Instruções práticas para pesquisas de Antropologia física e cultural. São Paulo: Departamento de Cultura, 1936.

SPIELMANN, Ellen. La desaparición de Dina Lévi-Strauss y el transvestismo de Mário de Andrade: Enigmas genealógicos en la historia de las ciencias sociales y humanas del Brasil moderno (series Báire, bi-lingua, espanhol/german, ed. Ellen Spielmann/ Antonio Arnoni Prado), Berlin: Wissenschaftlicher Verlag, 2003.

\section{Resumo}

Travessia transatlântica nos anos 1920 e 1930: as trajetórias da vanguarda poética e científica europeia no Brasil

$O$ artigo trata de quatro casos paradigmáticos de viajantes. A parte central está dedicada a Dina Lévi-Strauss, quem ministrou o primeiro curso de etnografia moderna no Brasil, apresentando nele o que havia de mais recente em sua época; seus projetos ainda incluíam a fundação de um museu etnográfico concebido a partir do modelo do "Musée de l'Homme". Por sua vez, Claude Lévi-Strauss e Fernand Braudel viajaram a São Paulo como membros da Missão francesa, que teve um papel importante na fundação da Universidade de São Paulo, mesmo que, por razões políticas, o contrato de Claude Lévi-Strauss não tenha sido renovado pela Universidade em 1937. Antes deles, Blaise Cendrars era já um poeta famoso quando cruzou o Atlântico em 1924. O fascismo na Europa e a Segunda Guerra Mundial interromperam as carreiras destes quatro viajantes tanto quanto seus intercâmbios com o Brasil e com seus amigos brasileiros. Contudo, as experiências que Claude Lévi-Strauss e Braudel levaram a cabo no Brasil foram cruciais para o sucesso de suas respectivas carreiras após 1945.

Palavras-chave: Cruzamentos transatlânticos século XX, história da ciência, vanguarda poética e científica, Universidade de São Paulo, Dina e Claude Lévi-Strauss, Fernand Braudel, Blaise Cendrars, Paulo Prado, Musée de l'Homme. 